\title{
UNIVERSITIES AND \\ REGIONAL ECONOMIC \\ DEVELOPMENT
}

ENGAGING WITH THE PERIPHERY

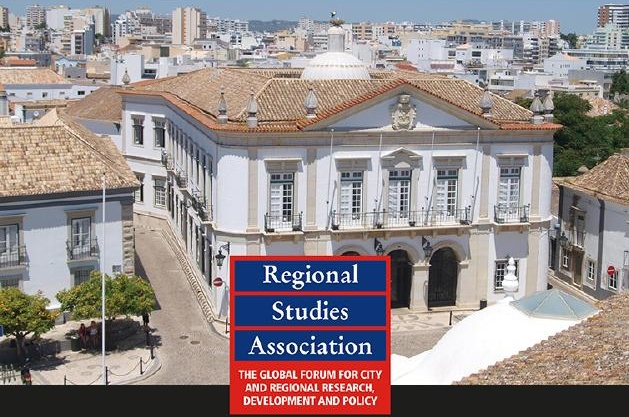

REGIONS AND CITIES

EDITED BY PAUL BENNEWORTH 


\section{Universities and Regional Economic Development}

In a knowledge-based economy, universities are vital institutions. This volume explores the roles that universities can play in peripheral regions, contributing to processes of regional economic development and innovative growth.

Including a series of case studies drawn from Portugal, Norway, Finland, the Czech Republic, Estonia and the Dutch-German border region, this will be the first book to offer a comprehensive comparative overview of universities in European economically peripheral regions. These studies seek to explore the tensions that arise in peripheral regions where there may not be obvious matches between university activities and regional strengths.

Aimed at academics, policy-makers and practitioners working on regional innovation strategies, this volume brings a much-needed sense of realism and ambition for all those concerned with building successful regional societies at the periphery of the knowledge economy.

Paul Benneworth is a senior researcher at the Center for Higher Education Policy Studies, University of Twente, the Netherlands, and Agderforskning, Kristiansand, Norway. 


\title{
Regional \\ Studies \\ Association \\ THE GLOBAL FORUM FOR CITY \\ AND REGIONAL RESEARCH, \\ DEVELOPMENT AND POLICY
}

\section{Regions and Cities}

\author{
Series Editor in Chief \\ Joan Fitzgerald, Northeastern University, USA
}

\section{Editors}

Ron Martin, University of Cambridge, UK

Maryann Feldman, University of North Carolina, USA

Gernot Grabher, HafenCity University Hamburg, Germany

Kieran P. Donaghy, Cornell University, USA

In today's globalised, knowledge-driven and networked world, regions and cities have assumed heightened significance as the interconnected nodes of economic, social and cultural production, and as sites of new modes of economic and territorial governance and policy experimentation. This book series brings together incisive and critically engaged international and interdisciplinary research on this resurgence of regions and cities, and should be of interest to geographers, economists, sociologists, political scientists and cultural scholars, as well as to policy-makers involved in regional and urban development.

For more information on the Regional Studies Association visit www.regionalstudies.org

There is a $\mathbf{3 0 \%}$ discount available to RSA members on books in the Regions and Cities series, and other subject related Taylor and Francis books and e-books including Routledge titles. To order just e-mail Joanna Swieczkowska, Joanna.Swieczkowska@, tandf.co.uk, or phone on +44 (0)20 33773369 and declare your RSA membership.You can also visit the series page at www.routledge.com/Regions-and-Cities/book-series/ RSA and use the discount code: RSA0901

\section{Universities and Regional Economic Development}

Engaging with the Periphery

Edited by Paul Benneworth

\section{Territorial Designs and International Politics}

Inside-out and Outside-in

Edited by Boaz Atzili and Burak Kadercan

\section{Smart Transitions in City Regionalism}

Territory, Politics and the Quest for Competitiveness and Sustainability

Tassilo Herrschel and Yonn Dierwechter

\section{Geopolitics of the Knowledge-Based Economy}

Sami Moisio 


\section{Universities and Regional Economic Development \\ Engaging with the Periphery}

Edited by Paul Benneworth 
First published 2019

by Routledge

2 Park Square, Milton Park, Abingdon, Oxon OX14 4RN

and by Routledge

711 Third Avenue, New York, NY 10017

Routledge is an imprint of the Taylor \& Francis Group, an informa business

(C) 2019 selection and editorial matter, Paul Benneworth; individual chapters, the contributors

The right of Paul Benneworth to be identified as the author of the editorial material, and of the author for his individual chapters, has been asserted in accordance with sections 77 and 78 of the Copyright, Designs and Patents Act 1988.

All rights reserved. No part of this book may be reprinted or reproduced or utilised in any form or by any electronic, mechanical, or other means, now known or hereafter invented, including photocopying and recording, or in any information storage or retrieval system, without permission in writing from the publishers.

Trademark notice: Product or corporate names may be trademarks or registered trademarks, and are used only for identification and explanation without intent to infringe.

British Library Cataloguing-in-Publication Data

A catalogue record for this book is available from the British Library

Library of Congress Cataloging-in-Publication Data

A catalog record has been requested for this book

ISBN: 978-1-138-05127-0 (hbk)

ISBN: 978-1-315-16835-7 (ebk)

Typeset in Bembo

by Out of House Publishing 
Dedicated to Martha Barbara Benneworth 


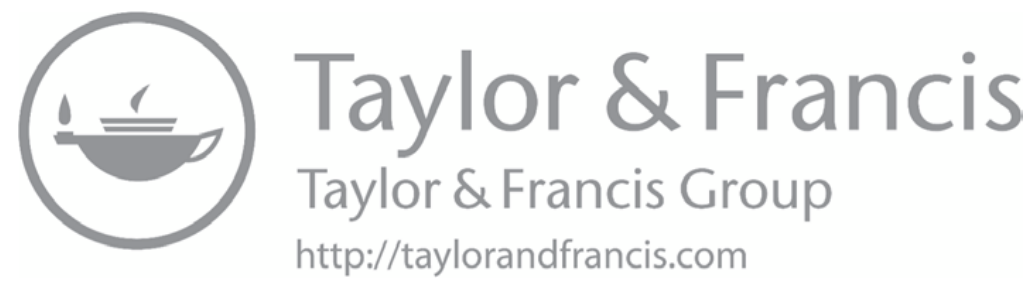




\section{Contents}

List of figures ix

List of tables $\quad \mathrm{x}$

Notes on contributors $\quad$ xi

Preface xiii

1 Universities and regional development in peripheral regions 1 PAUL BENNEWORTH AND LISA NIETH

2 Universities and neo-endogenous peripheral development: towards a systematic classification

3 Towards a strategic alignment: regional challenges and university tensions in peripheral geographies

4 University roles in a peripheral Southern European region: between traditional and 'engaged' roles through the provision of knowledge intensive business services HUGO PINTO, ELVIRA UYARRA AND MANUEL FERNÁNDEZ-ESQUINAS

5 'Strange bird': a peripheral university college in a complex, peripheral region JAMES KARLSEN

6 The case of the Telemark region and the university college of Telemark 
viii Contents

7 Vysočina region: from a remote rural region straight into the virtual world

LIBOR PRUDKÝ AND MICHAELA ŠMÍDOVÁ

8 Usti region: learning hard about industry modernisation INNA ČÁBELKOVÁ AND JAN KOHOUTEK

9 Higher education institutions at the periphery of the periphery: creating sustainable economic development in Estonia

ANNE KEERBERG

10 Universities and regional economic development in cross-border regions

JOS VAN DEN BROEK, FRANZISKA ECKARDT AND

PAUL BENNEWORTH

11 Constructing regional resilience in a knowledge economy crisis: the case of the Nokia-led ICT industry in Tampere

HELI KURIKKA, JARI KOLEHMAINEN AND MARKKU SOTARAUTA

12 Conceptualising the university-region economic development interface in peripheral regions

PAUL BENNEWORTH AND LISA NIETH

13 Future perspectives on universities and peripheral

regional development

LISA NIETH AND PAUL BENNEWORTH

Index 


\section{Figures}

2.1 The role of RICs in developing new trajectories 19

4.1 Map of the Algarve 48

5.1 Finnmark's location within Northern Norway 62

7.1 General design of our research 94

7.2 The location of Vysočina in the Czech Republic 95

8.1 The location of Usti in the Czech Republic 114

9.1 Regional HEI units outside university cities (Tartu and Tallinn) 132

10.1 The EUREGIO 151

11.1 ICT employment changes in Tampere region 169

11.2 Turnover development of the ICT sector in Tampere region 171

13.1 Key take-away messages for national policy-makers 197

13.2 Key take-away messages for regional policy-makers 199

13.3 Key take-away messages for university senior managers 201

13.4 Key take-away messages for university engagement support
activities

13.5 HEIs are integrated knowledge communities involving regional partners 206

13.6 Key take-away messages for engaged academics 207 


\section{Tables}

2.1 Varieties of path creation

2.2 Possible challenges for peripheral regions identified by diverse scholars

2.3 Possible responses of universities to lock-in scenarios 21

4.1 Key variables of Algarve, Portugal and Europe 49

5.1 Population development in sub-regions in Finnmark and Norway from 1950 to 2016

5.2 Summary of main regional development challenges of the sub-regions of Finnmark

5.3 Operationalising the HEI - regional tensions 67

6.1 Distribution of employees by sector in Telemark, Q4 2015

6.2 The campus locations comprising TUC, c. $2013 \quad 83$

6.3 Research groups at TUC 84

7.1 Education of population of Vysočina region compared to Czech Republic

7.2 Development of selected pollution and environmental expenditure in Vysočina

7.3 Focus of VŠPJ's study programmes and relation to developmental needs of Vysočina region 101

7.4 Applicants, students and graduates of VŠPJ 102

7.5 Study fields and numbers of students 102

9.1 Institutions providing higher education curricula, 1995-2016 131

9.2 Number of students at institutions providing higher education curricula, 1995-2014

9.3 Main characteristics of Estonian public universities' regional colleges, 2015-2016

10.1 Possible university contributions to addressing institutional gaps in CBRISs 


\section{Contributors}

Paul Benneworth is a senior researcher at the Center for Higher Education Policy Studies at the University of Twente, Enschede, The Netherlands and at Agderforskning, Kristiansand, Norway.

Jos van den Broek is a senior researcher at the Rathenau Instituut, The Hague, The Netherlands.

Inna Čábelková is an assistant professor and the head of the Qualified Skills Department at the Faculty of Humanities, Charles University, Prague, the Czech Republic.

Franziska Eckardt is a $\mathrm{PhD}$ student at the Center for Higher Education Policy Studies at the University of Twente, Enschede, The Netherlands.

Manuel Fernández-Esquinas is a research scientist at the Spanish National Research Council (CSIC).

James Karlsen is an associate professor at the University of Agder, Norway, a senior researcher at Agderforskning, Kristiansand, Norway, and a senior associate researcher at Orkestra, Basque Institute of Competitiveness, Spain.

Anne Keerberg is a $\mathrm{PhD}$ student at Tallinn University of Technology (TTÜ), Finland, researching higher education institutions and regional development.

Jan Kohoutek is a senior researcher at the Centre for Higher Education Studies in Prague and an assistant professor at the Faculty of Social Sciences, Charles University, Prague, the Czech Republic.

Jari Kolehmainen is Research Director at the University of Tampere, Faculty of Management, Urban and Regional Studies Group (Sente), Finland.

Heli Kurikka is a researcher at the University of Tampere, Faculty of Management, Urban and Regional Studies Research Group (Sente), Finland.

Nina Kyllingstad is a $\mathrm{PhD}$ candidate at the Department of Working Life and Innovation at the University of Agder, Norway and a researcher at Agderforskning, Kristiansand, Norway. 
xii Contributors

Lisa Nieth is a PhD student at the Center for Higher Education Policy Studies at the University of Twente, Enschede, The Netherlands.

Rómulo Pinheiro is a senior researcher (part-time) at Agderforskning, Kristiansand, Norway and Professor of Public Policy and Administration at the University of Agder, Norway.

Hugo Pinto is a researcher at the Centre for Social Studies, University of Coimbra (Portugal) and Professor in the Faculty of Economics, University of Algarve.

Libor Prudký is an associate professor at the Faculty of Humanities, Charles University, Prague, the Czech Republic.

Michaela Šmídová is a researcher at the Centre for Higher Education Studies, Prague, the Czech Republic.

Markku Sotarauta is Professor of Regional Development Studies in the Faculty of Management at the University of Tampere, Finland.

Elvira Uyarra is Senior Lecturer in Innovation Management and Policy at Alliance Manchester Business School (University of Manchester). 


\section{Preface}

The cliché is that science is a team game, with the result being more important than the individual who scores the goal. However, all of us in science know that we are all under immense pressure to perform as individuals. We are measured, monitored and managed as individuals, whilst the business of creating interesting and useful new knowledge is a collective affair. It has therefore been a great privilege to work as part of a dynamic, enthusiastic and dedicated group of scholars who are keen to explore the roles of universities in peripheral regions. Although ultimately it is my name that stands on the cover as editor, in this preface I wish to draw attention to and recognise the contribution of participants in our wider scholarly community that have made this volume possible.

This book reports results coming out of the PERIF-EU project, a collaboration between Agderforskning in Norway and a number of higher education research centres in the Czech republic. Many thanks are due to Rómulo Pinheiro, senior researcher at Agderforskning, for acquiring and overseeing the project and supporting my participation in the project through AF.The project was a fascinating opportunity to concentrate on truly peripheral regions, and the core set of case studies was sufficiently exciting to help enrol a list of other researchers with their own cases to contribute to this volume. The research leading to these results has received funding from the Norwegian Financial Mechanism 2009-2014 and the Czech Republic's Ministry of Education, Youth and Sports under Project Contract no. MSMT-5397/2015. I am a very demanding editor to work with, and I'd like to thank all the authors in this volume for their willingness to submit to my dictates as well as their patience as I suffered with RSI over the summer of 2017.

A word of thanks is certainly due to the publishers, Routledge, and in particular their dedicated staff on the Regions and Cities series who worked with me on this volume, namely Lisa Lavelle, Emily Kindleysides, Elanor Best and Natalie Tomlinson. This is my fourth volume in this series, something that reflects the great enthusiasm and support they provide their editors with, at a time when academic publishers are increasingly driven by profits rather than the nurturing of new ideas. It has been a great pleasure to work with them on this volume, and I hope to continue this relationship into the future. 
The last year has also seen some rather unpleasant shocks. One year ago we received the unexpected news of the passing of Professor Susan Christopherson, editor of this series. She has been a great inspiration to all of us in the field of economic geography, and made a number of leading contributions to debates around innovation, universities and uneven development. As we were finalising the volume, we were also told of the untimely death of our colleague on the PERIF project Olga Šmídová. Although she was not a contributor directly to this volume, she was an enthusiastic participant in the project meetings and the email discussions in which the ideas presented in this volume emerged. Our thoughts have been with those nearest and dearest to Olga and Susan, and they are being sorely missed by us both professionally but also personally.

Finally, an acknowledgement is also due to Martha Barbara. When I submitted the proposal on 17 October 2016 to the publisher from the Coffee Bar in C pier of Schiphol en route to Lisbon for a meeting of the Forskningsrådetfunded Digitalize or Die project, we hoped that we'd not be seeing you for another six weeks. But you popped out at the end of the week, and thankfully you have grown as rapidly as the manuscript. Your growth has been an inspiration to me as I have sought to finalise this volume and I am delighted to have both a healthy happy daughter and my long-dreamed-of volume on universities and regional development in the periphery. The making of this volume was inextricably bound up with you, and for that reason, I dedicate this volume to you, Martha Barbara Benneworth. 